\title{
A Research on the Perception of Architecture Students about Straw-Bale Buildings
}

\author{
Yasemin Erbil ${ }^{1}$, Çiğdem Yücel ${ }^{2}$, R.Tuğba Kızılkuşak ${ }^{3}$
}

\begin{abstract}
:
Although straw-bale construction has been used for thousands of years, currently doesn't attract considerable attention by professional architects and students. The reason behind this is assumed to be the prejudices and lack of knowledge about straw-bale buildings. In the scope of this research understanding candidate architects point of view on the preference criterias that are effective about choice of straw-bale construction is aimed. For this purpose, among 214 students of private university (in Turkey) in 2015-2016 academic year, 100 students were selected through simple random sampling and the survey was conducted. The results show that according to the candidate architects, the properties such as its being compatible to nature, harmless to human health, recyclable and low-cost are the main positive qualities of straw-bale construction, whereas lifetime, structural properties and fire resistance are still calling into question. This study demonstrates that straw bale construction techniques, which have the potential to solve environmental problems, need to be given more attention in the architecture educational.
\end{abstract}

Keywords: Straw-bale construction, preference criterias, architecture students

\section{Introduction}

As the environmental damage buildings can cause become an increasingly available knowledge, sustainable and ecological building materials and techniques are being sought- one of which is straw bale construction (Gross, 2009: 1-3). Straw is a renewable plant product that grows through photosynthesis, using sun as its fuel. It is grown annually through grain production, which means it is renewed every year. Straw is generally utilized for animal feeding, biofuel and in manufacture of panels; but its potential as a material for mainstream construction is being increasingly noticed due to its environmental benefits (Lawrence et al., 2009: 2763-2768). The most important of these are a savings in embodied energy, its sustainable nature as a material and the improved thermal performance of the buildings made using straw bales (Magwood et al., 2005: 1-2).

The buildings built using straw bales breathe. Because their heat conductivity resistance is very high, straw bale walls do not need extra insulating material. It decreases the amount of fuel needed to warm and cool and eliminates the use of insulating materialthis is why it is highly affordable. A straw bale building supports personal creativity, giving people the freedom to contribute to the making process of the places they will live in. Constructing a building using straw bales requires less labour force and craftsmanship than building with materials like concrete, adobe or stone. The fact that this material is cheap, that it can be applied easily and in a short amount of time by everybody decreases

\footnotetext{
$\mid{ }^{1}$ Uludag University, Faculty of Architecture, Associate Professor, PhD.

${ }^{2}$ Uludag University, Faculty of Architecture, PhD.

${ }^{3}$ METU, Faculty of Architecture.
} 
the overall cost significantly (Eryıldız and Başkaya, 2000: 87-104) Their cost-effective nature is not the only advantage of using straw bale as building materials: Straw bale buildings have the quality of earthquake and fire resistance, also they show sharp sound and heat insulation rates that are nearly ten times as much as those belonging to brick and wood, and a requirement of minimum maintenance (Gowini, 2002:1-2).

Some properties to straw bale buildings that must be considered when constructing are voids, pinning, water protection, details, and precompression (King, 2006:1-5). Garas argues that 'with proper attention to moisture control, a straw bale structure should be able to last as long as any conventional wood framed home' (Garas et al., 2009:54-59). In spite of its disadvantages, built environment professionals find that these impediments can easily be rendered harmless and recognize straw as an exceptional construction material (Ashour et al., 2011:1960-1967).

There are three types of straw bale construction techniques based on the type of structure resistance: load bearing straw bale structure, straw bale construction using timber frames, and straw bale construction with prefabricated walls (Adedeji and Bello, 2011:255-262).

The former method, also called Nebraska-style building, uses bales of wheat straw. It is a simple and flexible design, but the main reason builders choose this style is due to its thermal efficiency and affordable nature. Also, the uncomplicated nature of the method allows everybody, even people without training, to do the job just by following the basic principles of it. In this method, bales are gathered together as masonry blocks and they are pinned to the base by wooden pales. In buildings with ground and first floors, a wooden base is positioned around the walls between the two levels. Its flexible nature allows windows and doors to be arranged in multiple ways. The fact that the straw bales are used as building blocks that take the weight of the roof eliminates the need for a contiguous structure. These features make the method particularly fitting for the construction of experimental buildings (Hodge, 2006:49-78).

These Nebraskan style buildings are most commonly planned in square or rectangular shapes. The advantages of this method can be listed as the simplicity of the design and the construction processes, as well as the gain in money, time, material and work force. Nevertheless, the limitations in the design (the roofing cannot be too heavy), the need for straight and dense bales, and the time needed for the walls to adapt to the weight of the roof system are among the disadvantages of this style of building (Myhrman and MacDonald, 1997:15-20). The problem of having to keep the straw dry along the construction process can be minimized by the pre-fabrication of the building components so the bales will not have to be subjected to harsh weather conditions for a long time. The floor and the roof can also be used for weather protection (Jones, 2009:67-68) (Hollis, 2005:11-13). When using the load bearing method, as long as there aren't any openings on the bale wall, the resistance and durability of it cannot be questioned. Upper windows do not affect the endurance of the building, yet, positioning all the openings on a single wall is not very wise. Another matter on the subject is the distance between the openings as well as the distance between an opening and a corner: neither of these should be less than one and a half bale height. Large openings necessitate durable lintels or an endurable roof structure that can hold the roof weight 
over the opening. For this reason, openings should be narrow and elevated, not large and low (Myhrman and MacDonald, 1997:41-118).

Straw bale construction using timber frame structures is a method that was first used in the United States in the late 1970s. With this style of building, the weight of the roof is taken by a wooden frame, which leaves the bales as filler with no charge. In this case, it is important that the design should include a correlation with the size of the bales that are to be used - but even then, the bales can easily be resized for the needs of the building. The part that requires the most attention is the preparation of the bales for the plastering process. The straw pieces that protrude out of the long wire are cut to maintain a neat look. It is important for straw bale construction using timber frames that the bundles are compressed tightly, so as to limit heat loss. This is why the additional compression of the wall and the bales is recommended prior to the plastering process.

The most productive way that reaps the benefits of a straw bale construction is to use prefabricated walls. These walls are perfectly straight; vertical space is filled solely with straw and the need for other materials is eliminated. This way, the occurrence of gaps after pressing the bale is avoided and it is perfectly secure on its own (Cantor, 2015:1723).

The straw bale construction technique is one that has been used for hundreds of years due to its healthy and cost-effective nature. Compared to other construction techniques it requires less labour force and craftsmanship- it can be applied by anyone easily and it a short amount of time. In spite of all these advantages and its common use around the world it is not sufficiently known. Some of the recent examples of the use of straw bale construction in Turkey can be listed as Hasandede Ecovillage (Kirikkale/2000), Kerkenes Stone Warehouse (Yozgat/2008), Güneşköy Ecovillage (Kır1kkale/2000), Buğday Association Building (İstanbul/2006), Gündönümü Farm (İstanbul/2006), Afyon Saman House (Afyon/2013), Cezmi Saday Organic Farmhouse (Konya/2009), Nazım House (Aydın/2014), Naim and Feride Gün House (Datça/2014), Turgutlar İmece House Ecovillage (İzmir/2012), Kızılltepe-Bayramiç Ecovillage (Çanakkale/2014), Yeniköy Farmhouse (Çanakkale/2012), Kartal Strawbale Cafe (İstanbul/2012), Nevşehir Farmhouse (Nevşehir/2012), Dutoba House (Antalya/2013), Naim and Feride Gün House (Kütahya/2010), Yeryüzü Association, Pamukova Ecovillage (Sakarya/2014), Yalova Farmhouse (Yalova/2014).

When compared to its application around the world, straw bale construction in Turkey is not adequately known. The reason behind this is the prejudice against buildings constructed with the straw bale technique as well as the lack of knowledge on the subject. With this in mind, a research has been conducted using architecture students.

\section{Methodology}

In this study aiming to reveal the opinions of architect candidates about the criteria which can be effective in preference to the structures built with straw bale construction technique, a sample consisting of 100 students selected by easy sampling method among 214 students studying in the Department of Architecture of a private university in Turkey in 2015-2016 academic year was created. Since there are no students who are studying in the $4^{\text {th }}$ grade, the students attending $1^{\text {st }}, 2^{\text {nd }}$ and $3^{\text {rd }}$ classes are 
included in the study. The data which is outcome of the research is achieved by using survey method. In the first section of three-part questionnaire, introductory information is placed. There are questions for learning the gender, age and classes of the students. In the second part of the research, participants were shown the images of the straw-bale buildings and they were asked if they prefer living in such a building constructed by this system. In the third part of the study, the potential criteria and sub criteria that could be effective in choosing straw-bale buildings were stated. These criteria are insulation properties, material, construction and detail properties, impact on human health, economical, sustainability, social and aesthetic characteristics, legislation and sectoral specialities. The questions prepared according to the determined criteria were directed to the participants and they were asked to respond according to the 5-point likert system. (Level of agreement: 1- I strongly disagree. / 2- I disagree. / 3- I have no idea. / 4- I agree. / 5- I strongly agree.) The obtained results were interpreted by presenting in graphical form.

\section{Results}

Demographic Features: Out of 100 students who participate to the research, 72 students $(72 \%)$ are female and 28 students $(28 \%)$ are male. Total number of students studying in the department of architecture is 214 students. Of these students, 152 were female $(71 \%)$ and 62 were male $(29 \%)$. The lower number of male students in the sample is owing to the lower number of male students in the department. $97(97 \%)$ of the students are under the age of 25 and $3(3 \%)$ are between the ages of 26-31. $43(43 \%)$ of the students in the research are studying in the $1^{\text {st }}$ grade, $53(53 \%)$ students are studying in the $2^{\text {nd }}$ grade and $4(4 \%)$ students are studying in $3^{\text {rd }}$ grade. The ratio of the students who answered "I prefer living in a building constructed by straw-bale" is $50 \%$ while the ratio of the students who answered "I do not prefer living in a building constructed by straw-bale" is $50 \%$.

The effect of its insulation features: The effect of insulation features on the preference of straw-bale buildings was inquired and results were demonstrated in Figure 1. To the statement of "Straw-bale buildings have adequate fire insulation properties"; $10 \%$ of the participants are answered "I strongly agree", 19\% are answered "I agree", 31\% are answered "I have no idea", 16\% are answered "I disagree" and 24\% are answered "I strongly disagree". To the statement of "Straw-bale buildings have adequate water insulation properties"; $12 \%$ of the participants are answered "I strongly agree", $24 \%$ are answered "I agree", 45\% are answered "I have no idea", 10\% are answered "I disagree" and $9 \%$ are answered "I strongly disagree". To the statement of "Straw-bale buildings have adequate sound insulation properties"; 17\% of the participants are answered "I strongly agree", 30\% are answered "I agree", 44\% are answered "I have no idea", 5\% are answered "I disagree" and 4\% are answered "I strongly disagree". To the statement of "Straw-bale buildings have adequate thermal insulation properties"; $21 \%$ of the participants are answered "I strongly agree", 29\% are answered "I agree", 40\% are answered "I have no idea", 5\% are answered "I disagree" and 5\% are answered "I strongly disagree". 


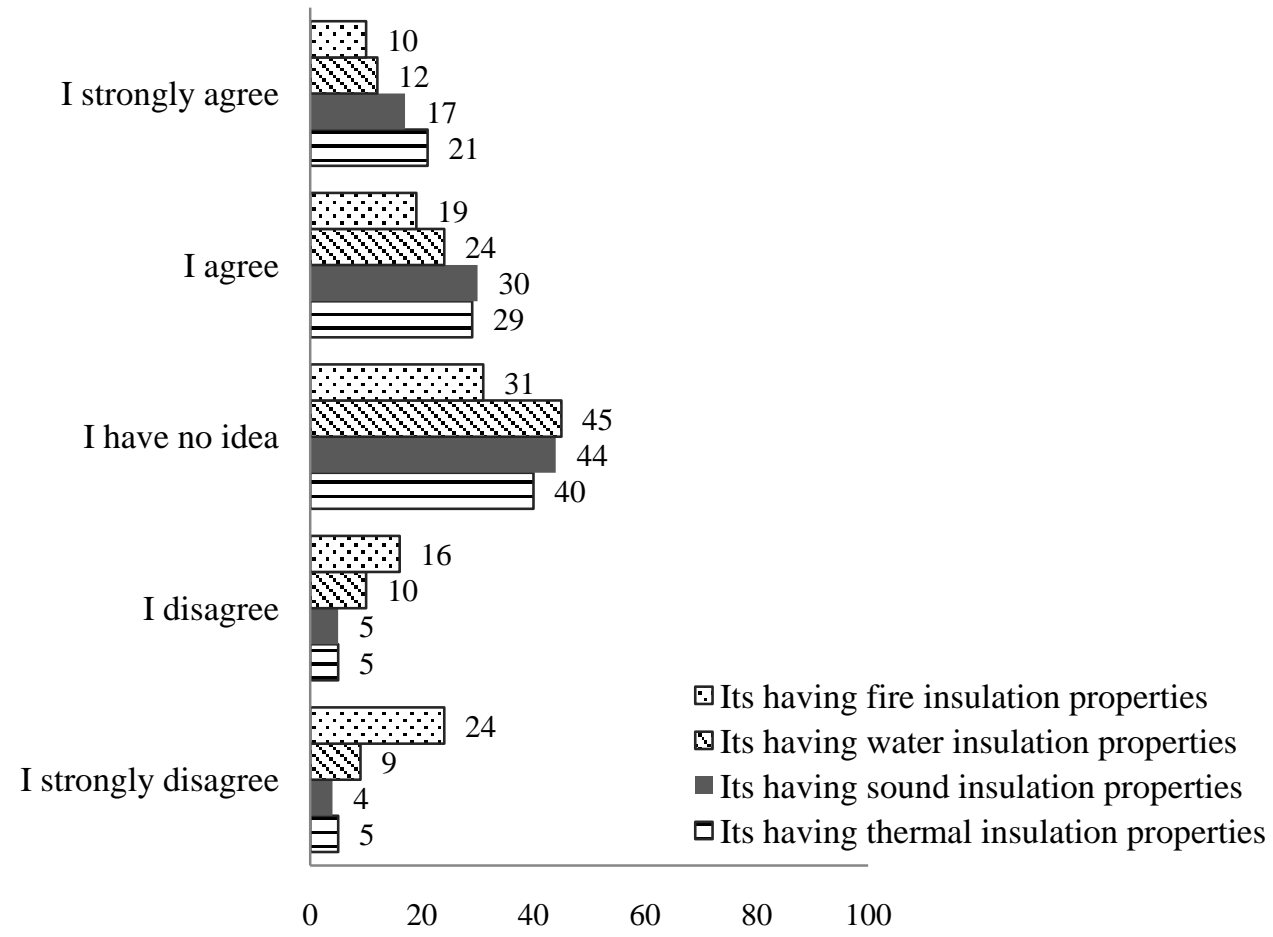

Figure 1. The Effect of Insulation Features

The effect of its material, construction and detail features: The effect of its material, construction and detail features on the preference of straw-bale buildings was inquired and results were demonstrated in Figure 2. To the statement of "Straw-bale is long-lasting"; 12\% of the participants are answered "I strongly agree", 14\% are answered "I agree", 37\% are answered "I have no idea", 21\% are answered "I disagree" and 16\% are answered "I strongly disagree". To the statement of "It is easy to supply straw-bale"; $15 \%$ of the participants are answered "I strongly agree", 42\% are answered "I agree", 33\% are answered "I have no idea", 9\% are answered "I disagree" and 1\% are answered "I strongly disagree". To the statement of "Straw-bale is a material of which performance is not satisfactory as a construction material"; $19 \%$ of the participants are answered "I strongly agree", 30\% are answered "I agree", 34\% are answered "I have no idea", 11\% are answered "I disagree" and 6\% are answered "I strongly disagree". To the statement of "Straw-bale is structurally durable material"; $13 \%$ of the participants are answered "I strongly agree", 15\% are answered "I agree", 37\% are answered "I have no idea", 18\% are answered "I disagree" and 17\% are answered "I strongly disagree". To the statement of "Detail solution of straw-bale buildings is easy"; $9 \%$ of the participants are answered "I strongly agree", 22\% are answered "I agree", 55\% are answered "I have no idea", 10\% are answered "I disagree" and 4\% are answered "I strongly disagree". 


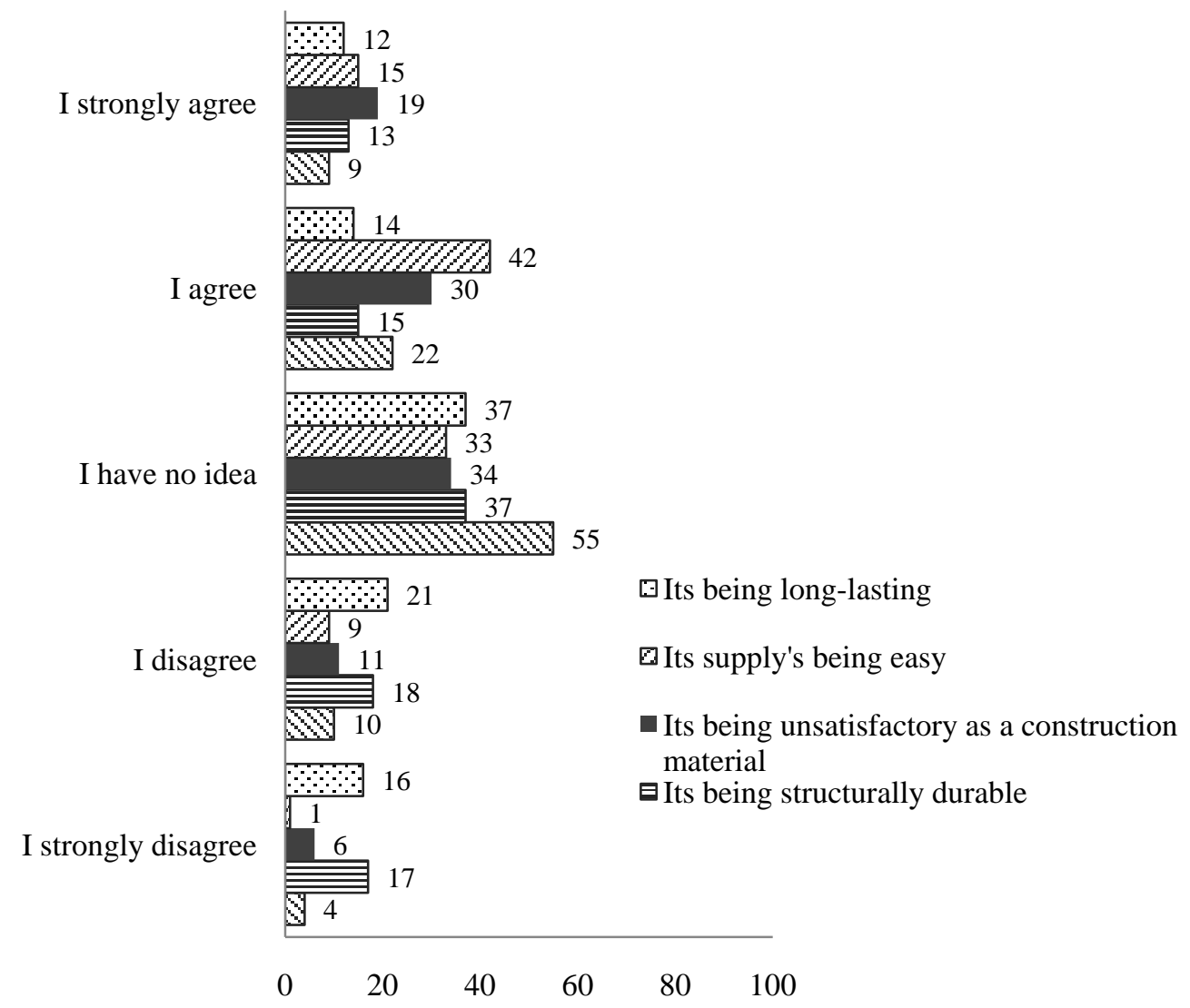

Figure 2. The Effect of Material, Construction and Detail Features

Impact on human health: The effect of the impact of material on human health on the preference of straw-bale buildings was inquired and results were demonstrated in Figure 3. To the statement of "The notion of "healthy building" is not an extensively known notion"; $19 \%$ of the participants are answered "I strongly agree", $36 \%$ are answered "I agree", 25\% are answered "I have no idea", 16\% are answered "I disagree" and 4\% are answered "I strongly disagree". To the statement of "Straw-bale buildings are not harmful to human health"; $40 \%$ of the participants are answered "I strongly agree", $26 \%$ are answered "I agree", 25\% are answered "I have no idea", 5\% are answered "I disagree" and $4 \%$ are answered "I strongly disagree". 


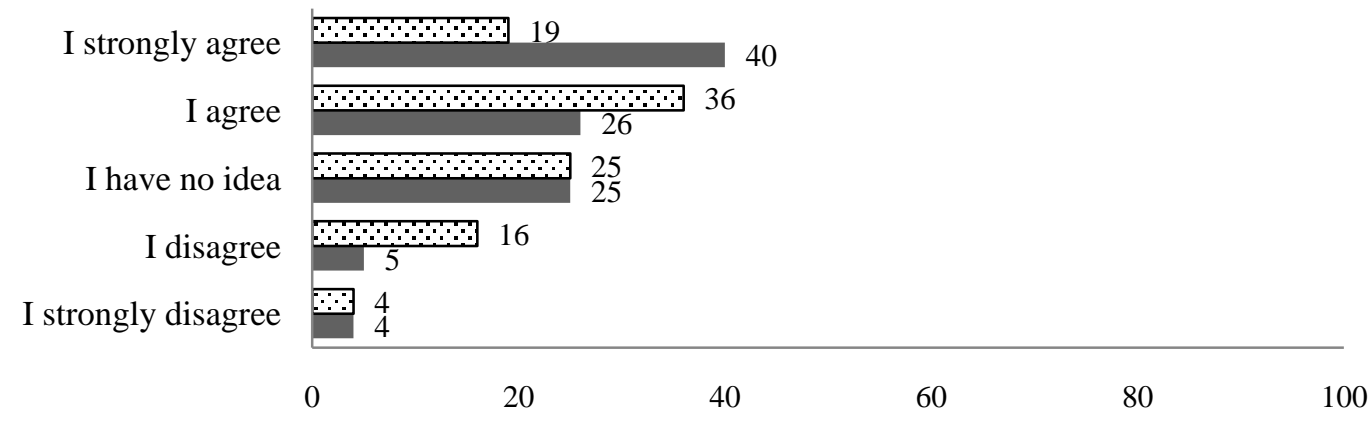

$\Xi$ The notion of "healthy building"s being uncommon $\square$ Its being harmless to human health Figure 3. The Impact on Human Health

The effect of economical features: The effect of its economical features on the preference of straw-bale buildings was inquired and results were demonstrated in Figure 4. To the statement of "Making an extraordinary practise increases the cost"; $12 \%$ of the participants are answered "I strongly agree", 31\% are answered "I agree", 34\% are answered "I have no idea", 18\% are answered "I disagree" and 5\% are answered "I strongly disagree". To the statement of "The maintenance cost of straw-bale is low"; $12 \%$ of the participants are answered "I strongly agree", $26 \%$ are answered "I agree", $43 \%$ are answered "I have no idea", $12 \%$ are answered "I disagree" and $7 \%$ are answered "I strongly disagree". To the statement of "The price of straw-bale is low"; $28 \%$ of the participants are answered "I strongly agree", 34\% are answered "I agree", 31\% are answered "I have no idea", 5\% are answered "I disagree" and $2 \%$ are answered "I strongly disagree".

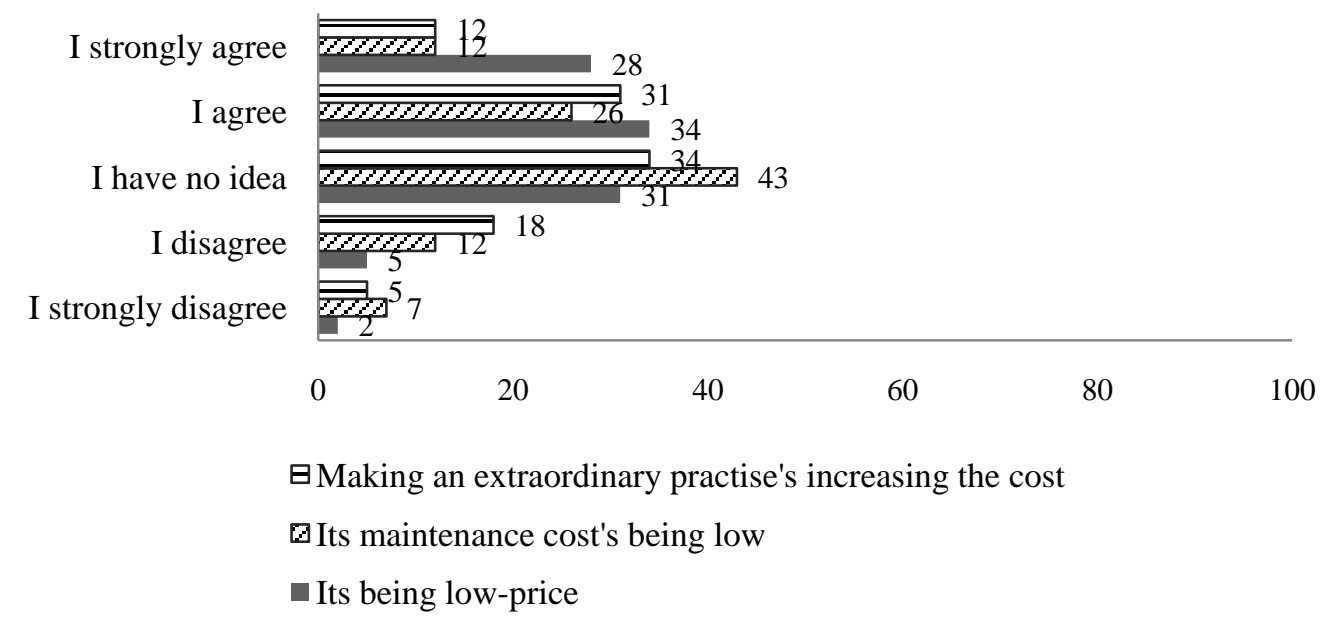

Figure 4. The Effect of Economical Features 
The effect of its sustainability features: The effect of its sustainability features on the preference of straw-bale buildings was inquired and results were demonstrated in Figure 5. To the statement of "Straw-bale is a material of which production energy is low"; $19 \%$ of the participants are answered "I strongly agree", 31\% are answered "I agree", 40\% are answered "I have no idea", $8 \%$ are answered "I disagree" and 2\% are answered "I strongly disagree". To the statement of "Straw-bale is a recyclable material"; $25 \%$ of the participants are answered "I strongly agree", 39\% are answered "I agree", 29\% are answered "I have no idea", 5\% are answered "I disagree" and 2\% are answered "I strongly disagree". To the statement of "Straw-bale is a material which is compatible with nature"; $43 \%$ of the participants are answered "I strongly agree", 26\% are answered "I agree", 25\% are answered "I have no idea", 4\% are answered "I disagree" and 2\% are answered "I strongly disagree".

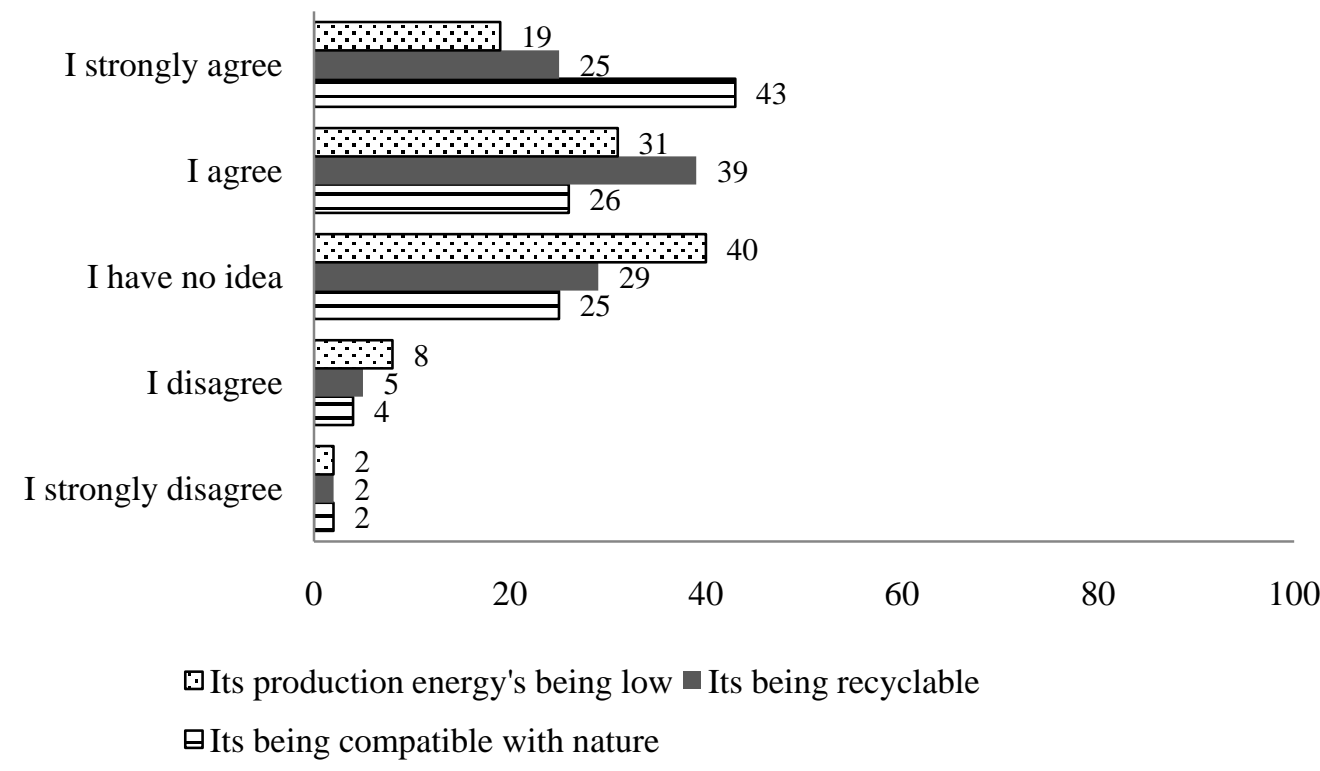

Figure 5. The Effect of Sustainability Features

The effect of its social and aesthetic features: The effect of its social and aesthetic features on the preference of straw-bale buildings was inquired and results were demonstrated in Figure 6. To the statement of "Nowadays, sensitivity to environmental aesthetic is missing"; $14 \%$ of the participants are answered "I strongly agree", $27 \%$ are answered "I agree", $41 \%$ are answered "I have no idea", 45\% are answered "I disagree" and 3\% are answered "I strongly disagree". To the statement of "People usually have a negative perception about straw-bale"; $22 \%$ of the participants are answered "I strongly agree", $27 \%$ are answered "I agree", 37\% are answered "I have no idea", 12\% are answered "I disagree" and $2 \%$ are answered "I strongly disagree". To the statement of "Straw-bale buildings bring old architecture to mind"; $16 \%$ of the participants are answered "I strongly agree", $37 \%$ are answered "I agree", 26\% are answered "I have no idea", 14\% are answered "I disagree" and 7\% are answered "I strongly disagree". To the statement of "The straw 
bale buildings allow the development of creative designs"; 13\% of the participants are answered "I strongly agree", $24 \%$ are answered "I agree", 43\% are answered "I have no idea", $14 \%$ are answered "I disagree" and 6\% are answered "I strongly disagree". To the statement of "The straw bale buildings are aesthetic"; $13 \%$ of the participants are answered "I strongly agree", 22\% are answered "I agree", 46\% are answered "I have no idea", $14 \%$ are answered "I disagree" and 5\% are answered "I strongly disagree". To the statement of "Straw bale is an accustomed material"; $13 \%$ of the participants are answered "I strongly agree", 26\% are answered "I agree", 31\% are answered "I have no idea", 16\% are answered "I disagree" and 14\% are answered "I strongly disagree".

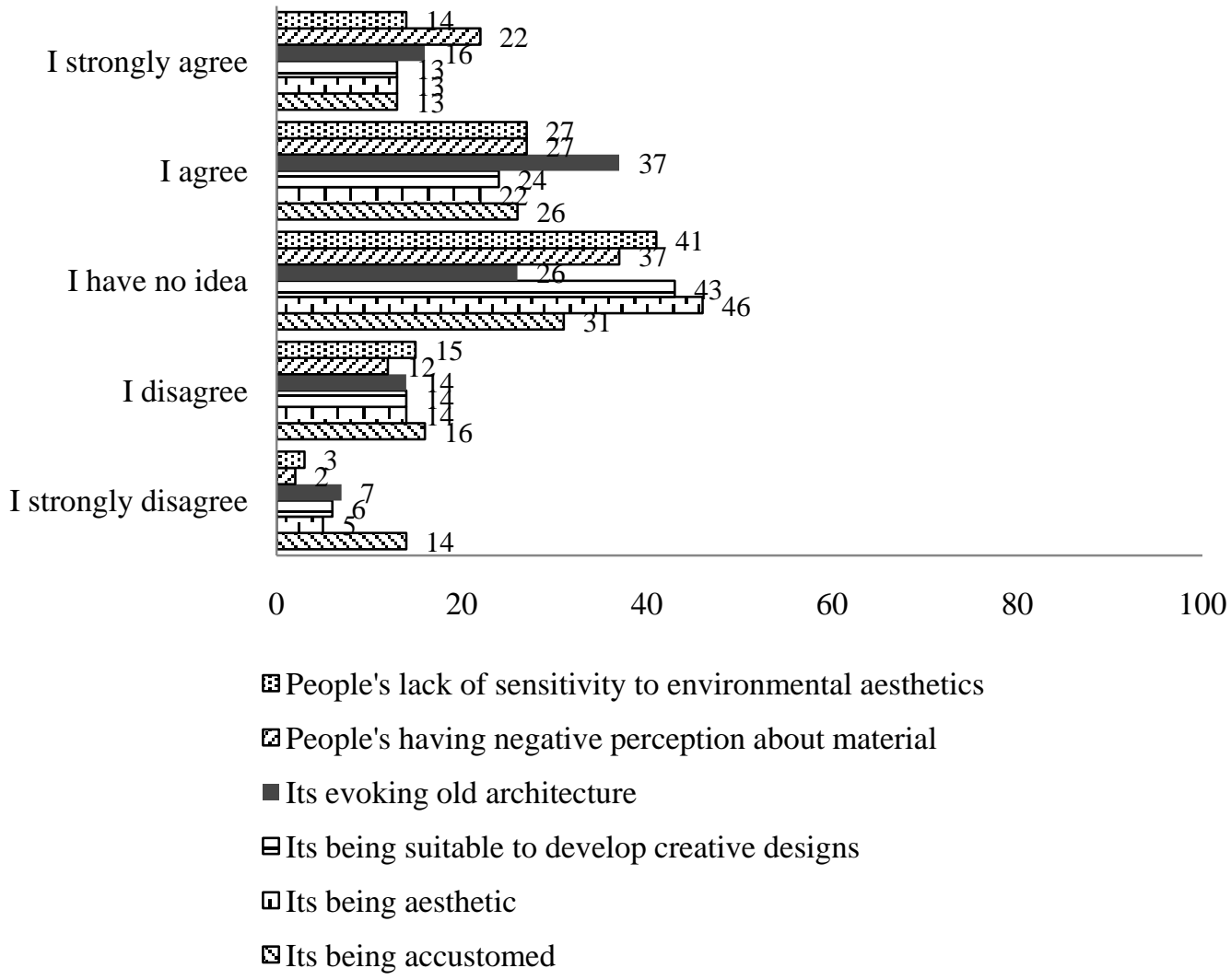

Figure 6. The Effect of Social and Aesthetic Features

The effect of legislation and sectoral features: The effect of legislation and sectoral features on the preference of straw-bale buildings was inquired and results were demonstrated in Figure 7. To the statement of "Technical knowledge and skills for straw-bale buildings is inadequate in construction sector"; $14 \%$ of the participants are answered "I strongly agree", 39\% are answered "I agree", 22\% are answered "I have no idea", 16\% are answered "I disagree" and 9\% are answered "I strongly disagree". To the statement of "Straw-bale buildings are not known enough by the professional architects, related 
managers and users"; $23 \%$ of the participants are answered "I strongly agree", 29\% are answered "I agree", 33\% are answered "I have no idea", 13\% are answered "I disagree" and $2 \%$ are answered "I strongly disagree". To the statement of "When it comes to the straw-bale buildings, there are potential difficulties in housing loans and insurance issues"; $20 \%$ of the participants are answered "I strongly agree", 30\% are answered "I agree", 40\% are answered "I have no idea", 8\% are answered "I disagree" and 2\% are answered "I strongly disagree". To the statement of "The straw bale buildings are not sufficiently located in the construction market"; $19 \%$ of the participants are answered "I strongly agree", 31\% are answered "I agree", 33\% are answered "I have no idea", 14\% are answered "I disagree" and 3\% are answered "I strongly disagree". To the statement of "There are some difficulties about finding manpower required for practising straw bale buildings"; $15 \%$ of the participants are answered "I strongly agree", 24\% are answered "I agree", 37\% are answered "I have no idea", 17\% are answered "I disagree" and $7 \%$ are answered "I strongly disagree". To the statement of "The technology required for implementing straw bale buildings is not dominant in the sector"; $18 \%$ of the participants are answered "I strongly agree", 24\% are answered "I agree", 35\% are answered "I have no idea", 18\% are answered "I disagree" and 5\% are answered "I strongly disagree". To the statement of "The legislation is inadequate about straw bale buildings"; $17 \%$ of the participants are answered "I strongly agree", $26 \%$ are answered "I agree", 44\% are answered "I have no idea", 9\% are answered "I disagree" and 4\% are answered "I strongly disagree". 


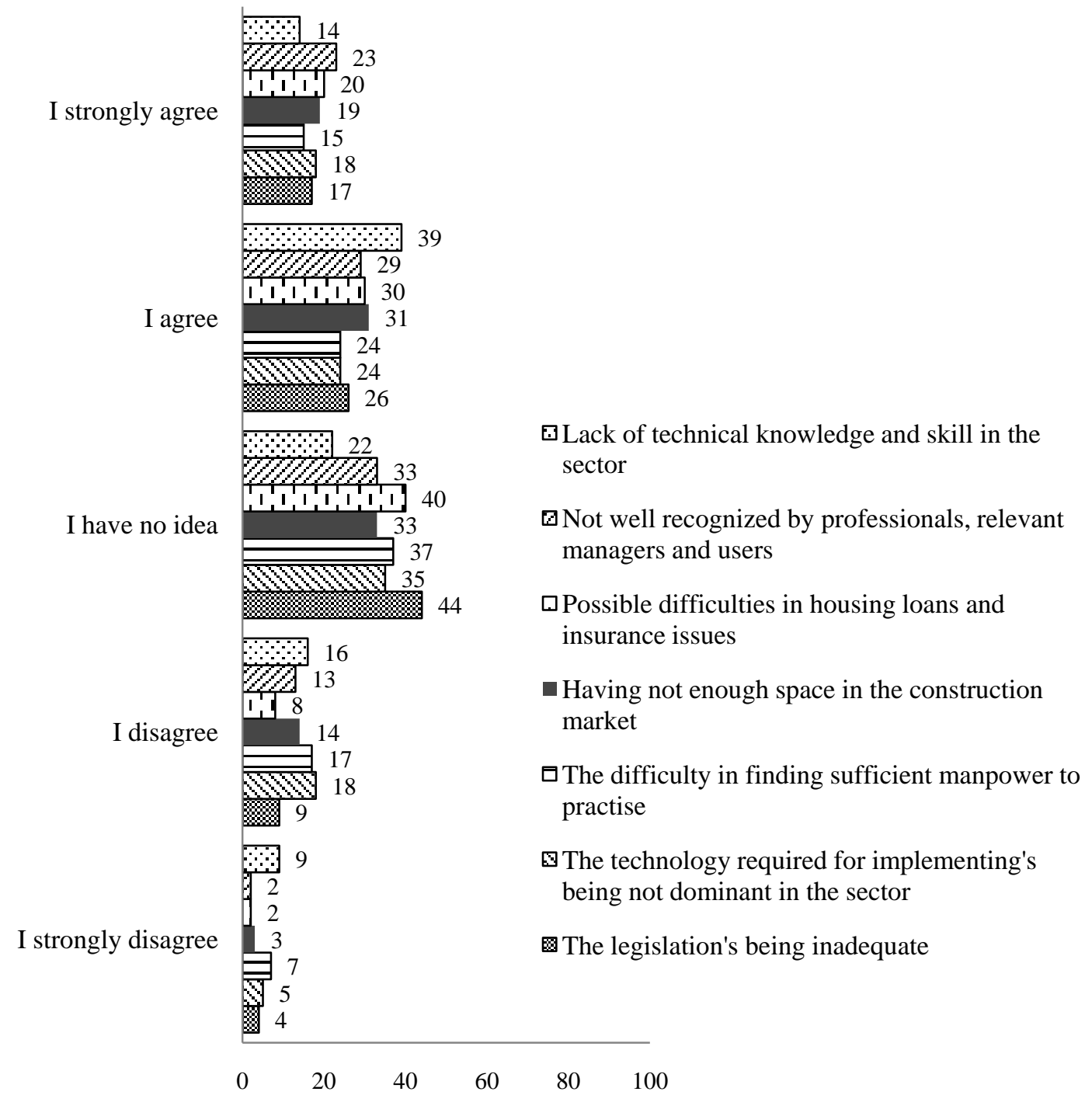

Figure7. The Effect of Legislation and Sectoral Features

\section{Conclusions}

Though the straw bale buildings have been used in the world for thousands of years, they are rarely encountered today. Straw bale buildings are not showed interest by professional architects and architecture students. The purpose of the paper is to put forward the criteria that may be effective in preferring straw bale buildings from the architecture students' point of view. The results of the research indicate that while the properties of straw bale such as its being compatible to the nature, harmless to human 
health, recyclable and low-cost are came into prominence, its lifetime, structural properties and fire resistance induce hesitation (Figure 8).

It is compatible to the nature

It can be recyclable

It is not harmfull to human health

It is easy to supply

It has enough heat insulation

It has enough fire insulation

Its maintenance cost is low

The production energy is low

It is an accustomed material

It has enough sound insulation

The sensitivity about environmental aesthetic is.

People usually have negative perception about material

Its cost is low

The notion of healthy building is not widespread

There is no enough space in construction sector

It has a long lifespan

It enables creative designs to develop

It is aesthetic

It evokes an old architecture

Technical information and skill is lacking in.

Since it is an uncommon practise its cost is high

It is not known enough by professionals, related.

The technology required for implementing is not.

Its performance is satisfactory as a construction material

It has sufficient water insulation

Its detail solution is easy

It is a structurally durable material.

It is difficult to find required manpower to practise

There can be difficulties in housing loans and.

Legislation is inadequate

0

0

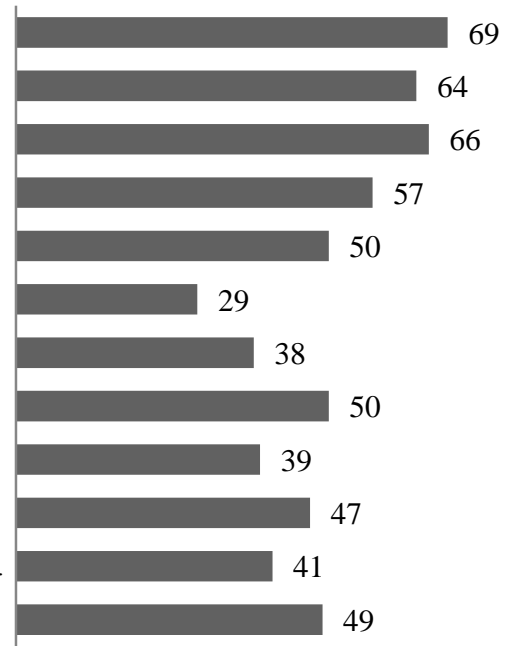

64

55

50

26

37

35

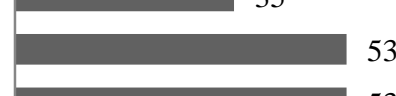

53

43

52

39

49

36

31

28

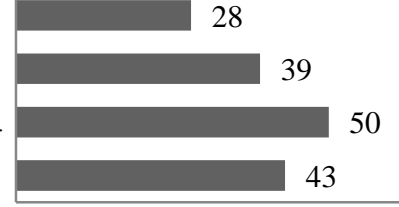

50

43

$60 \quad 80$

Figure 8. The Importance Degree of Criteria That may be Effective in Preferring Straw Bale Building (It is evaluated on the sum of the expressions 5="I strongly agree" and 4="I agree" in the graphic.) 
The results of the survey show that the environmental characteristics of the straw bale structures are recognized, but the structural and technical characteristics are not well known. When the programmes of architecture undergraduate education in Turkey are examined, it is seen that the applications of reinforced concrete, steel and wood are given priority in the direction of sectoral requirements. With studio works, workshops and scientific researches, it should be tried to contribute more to straw bale and construction techniques which have potential to solve our environmental problems.

\section{References}

Adedeji, A. A., Bello, J. A., (2011). Construction Procedure of a Straw Bale Walled Building - a review. Annals of Faculty Engineering Hunedoara - International Journal of Engineering, IX (3):255-262

Ashour, T., Georg, H., Wu, W., (2011). Performance of Straw Bale Wall: A Case of Study. Energy and Buildings, 43:1960-1967

Cantor, D. M., Manea, D. L., (2015). Using Wheat Straw in Construction, ProEnvironment 8:17-23

Garas, G., Allam, M., Dessuky, El R., (2009). Straw Bale Construction as an Economic Environmental Building Alternative- A Case Study. ARPN Journal of Engineering and Applied Sciences, 4(9):5459

Gowini, El M., (2002). Background About Rice Straw Problem in Egypt: (Is rice Straw Really Waste?) by Copyright Community Times, Cairo, Egypt. October, pp.1-2

Gross, C., (2009). Structural Performance of Prefabricated Straw-bale Panels. University of Bath: United Kingdom, pp.1-3

Hodge, B., (2006). Building Your Straw Bale Home: from Foundation to the Roof, CSIRO Publishing, Australia, 49-78

Hollis, M., (2005). Practical Straw Bale Building. CSIRO Publishing: Victoria, pp.11-13

Irkl1-Erylldı, D., Başkaya, A., (2000). Building With Straw-bales: Construction of a Prototype in KırıkkaleHasandede. J. Fac.Eng.ARch. Gazi Univ, 15(2):87-104

Jones, B., (2009). Building with Straw Bales: A Practical Guide for the UK and Ireland, 2, Green Books, Totnes, pp.67-68

King, B., (2006). Design of Straw Bale Buildings, Green Building Press, pp.1-5

Lawrence, M., Heath, A., Walker, P., (2009). Determining Moisture Levels in Straw-bale Construction. Construction and Building Materials, 23: 2763-2768

Magwood, C., Mack, P., Therrien, T., (2005). More Strawbale Building - A Complete Guide to Designing and Building with Straw. Canada: New Society, Gabriola Island, pp.1-2

Myhrman, M., Mac Donald, S. O., (1997). Build it with Bales: A Step-by-Step Guide to Straw Bale Construction. Version Two, Out on Bale, Tuscon, AZ, 15-118

Sodagar, B., Rai, D., Jones, B., Wihan, J., Fieldson, R., (2011). The Carbon-Reduction Potential of Straw-Bale Housing. Building Research \& Information, 39(1):61-65 